ORIGINAL ARTICLE

\title{
Gratitude is female. Biological sex, socio-cultural gender versus gratitude and positive orientation
}

\author{
Sebastian Skalski (D)A,B,C,D,E,F, Grzegorz Pochwatko (D) A,B,C,D,E,F \\ Institute of Psychology, Polish Academy of Sciences, Warsaw, Poland
}

BACKGROUND

According to previous studies, women experience emotions more frequently and intensively than men, and also reveal greater sensitivity to emotions of other people. Relationships turn out to be more complicated in the case of socio-cultural gender. The objective of the study was to search for relations between biological sex, socio-cultural gender, gratitude and positive orientation.

\section{PARTICIPANTS AND PROCEDURE}

The study involved 238 participants (125 women and 113 men). The average age of the participants was 33.28 $(S D=8.95)$. The following research tools were employed: the Masculinity and Femininity Scale, the Gratitude Questionnaire and the Positivity Scale. To determine the significance of differences, Student's $t$-test and analysis of variance (ANOVA) were used. In order to establish the relationships between variables, Pearson's correlation coefficient and linear regression were applied. The significance of the mediation model was tested using Sobel's test.
RESULTS

Biological sex and socio-cultural gender differentiated the results of gratitude. Femininity was associated with higher scores on the scales of gratitude and positive orientation. Gratitude showed a correlation with positive orientation.

\section{CONCLUSIONS}

Women exhibit a higher level of gratitude than men. Androgynous people show a higher level of gratitude than people who are sex-typed, undifferentiated and cross-sextyped. Sex-typed women show a higher level of gratitude compared to sex-typed men. Women who are cross-sextyped display a lower level of gratitude than cross-sex-typed men. Gratitude is a mediator of the relationship between femininity and positive orientation.

\section{KEY WORDS}

gender differences; socio-cultural gender; gratitude; positive orientation; femininity

Corresponding Author - Sebastian Skalski, Institute of Psychology, Polish Academy of Sciences, 1 Jaracza Str., 00-378 Warsaw, Poland, e-mail: sebastian.skalski@sd.psych.pan.pl

AUthors' CONTRIBUtION - A: Study design - B: Data collection - C: Statistical analysis - D: Data interpretation .

E: Manuscript preparation · F: Literature search · G: Funds collection

to Cite this ARTicle - Skalski, S., \& Pochwatko, G. (2020). Gratitude is female. Biological sex, socio-cultural gender

versus gratitude and positive orientation. Current Issues in Personality Psychology, 8(1), 1-9.

RECEIVED 04.12.2019 • REVIEWED 17.02.2020 • ACCEPTED 18.02.2020 • PUBLISHED 10.03.2020 


\section{BACKGROUND}

Gratitude is an interdisciplinary issue considered on the ground of various subjects including psychology, philosophy, theology and sociology. It plays an important role in the social life of humans and is widely appreciated among representatives of various cultures (Tucholska, 2017). Its subject matter is present in many religious systems, including Christianity, Islam and Hinduism. Gratitude is, however, a fairly new construct in clinical studies. The increase of its popularity stems in particular from the researchers' interest in the role of positive emotions in building the mental and physical wellbeing of people. Gratitude is a complex mental experience which appears as a result of one's awareness of the benefits which may be derived from someone else (Emmons \& Crumpler, 2000). It is a response to the goodness and kindness of the donor. Gratitude may be defined as disposition, positive emotion or psychological resource (Büssing et al., 2013; Polak \& McCullough, 2006). It often occurs with other pro-social characteristics (McCullough, Kilpatrick, Emmons, \& Larson, 2001). As per the broaden-andbuild theory of positive emotions, gratitude plays a crucial role in coping with stressors (Fredrickson, 2004b). It expands the repertoire of available behavior and leads to the broadening of individual resources, which, in turn, increases the ability of an individual to adapt to difficult situations. Gratitude motivates the creation of social bonds and the maintenance (tightening) of those already existing (Algoe, Haidt, \& Gable, 2008; Lambert \& Fincham, 2011), as well as counteracting destructive behavior towards other people (Emmons, 2009). It is considered an advantage of character that leads to a good life (Seligman \& Peterson, 2004). It is on the list of intentional influences that permanently increase the sense of happiness (Lyubomirsky, 2008). Previous studies reveal relationships between the level of the felt gratitude and subjective well-being, altruism, friendship or trust (Emmons \& McCullough, 2003; Fredrickson, 2004a; Gruszecka, 2011; Tsang, 2006; Tsang \& Martin, 2019; Valikhani, Ahmadnia, Karimi, \& Mills, 2019; Wolanin, 2016). Gratitude can also affect the state of physical health. Studies suggest its positive link with the functioning of the cardiovascular system or life expectancy (Danner, Snowdon, \& Friesen, 2001; McCraty, Atkinson, Tiller, Rein, \& Watkins, 1995).

Positive orientation combines three components in itself: optimism, self-esteem and life satisfaction. The conceptualization grew out of previous studies based on constantly repeated correlations and the results of factor analyses. The obtained data congruently suggested the single-factor model. Therefore, the existence was assumed of a general latent variable underlying the common basis of individual as- pects (Alessandri, Caprara, \& Tisak, 2012). The theoretical base appeared to be an attempt to identify variables for the reversal of Beck's (1967) depressive triad, i.e. negative beliefs about oneself, the world and the future. Positive orientation is responsible for the adaptive functioning of an individual. It affects self-esteem, pursuing goals and satisfaction with life (Caprara et al., 2012; Skalski, 2019).

Biological sex refers to a set of objective anatomical and biological features that an individual brings into the world (e.g. chromosomes, hormones or genitals). Socio-cultural gender is subjectively based on psychological characteristics and behavior of the individual. It was shaped on the basis of stereotypical definitions of femininity and masculinity, which are related to biological differences (Kuczyńska, 2002). In the Polish population, examples of such properties include romance and delicacy as attributes of femininity, as well as domination and courage as attributes of masculinity (Lipińska-Grobelny \& Gorczycka, 2011). Initially, the concept was considered in dichotomous terms. In 1974, Bem stated that individuals can have varying levels of feminine and masculine features (regardless of their biological sex). Thus, she rejected the bipolar division into femininity and masculinity. The author proposed four types to describe the socio-cultural gender: sextyped persons, androgynous persons, undifferentiated persons, and cross-sex-typed persons (Bem, 1974; Spence \& Helmreich, 1974). The first describes psychological characteristics that correspond to biological sex, i.e. feminine women and masculine men. The second refers to people who exhibit strong feminine and masculine characteristics at the same time. The third defines people whose socio-cultural gender characteristics have been shaped to a small extent. The last one concerns people who show characteristics that are opposite to their biological sex. The type of gender depends on whether the concept of "I" has been shaped on the basis of social definitions of femininity and masculinity. Socio-cultural gender is included in cognitive structures. It can determine the way information is processed and a specific behavior of an individual (Markus, Crane, Bernstein, \& Siladi, 1982).

Researchers argue that women are more emotionally expressive than men. They experience emotions more often and more intensively (with the exception of anger), and also reveal greater sensitivity to the emotions of other people (Brody, 1997; Shaffer, 2000; Wytykowska \& Petrides, 2007). They show a greater understanding of the emotions of others and they are better in analyzing situations which generate emotions. Men are more often expected to focus on tasks and attainment of goals, with a parallel limitation of the emotional sphere, without which the achievement of success would be problematic (Matczak \& Knopp, 2013). Previous studies sug- 
gest that men may connect gratitude with the sense of dependency on other people (Solomon, 1995; Trzebińska, 2005). They may also recognize showing gratitude as a sign of sensitivity that threatens their masculinity and social position (Ingoldsby, Horlacher, Schvaneveldt, \& Matthews, 2005; Levant \& Kopecky, 1995). On the other hand, women more openly express their emotions and are more likely to seek social support (Knopp, 2012; Schwartz \& Rubel, 2005), which is associated with socio-cultural femininity (Lipińska-Grobelny \& Gorczycka, 2011). Researchers confirmed that women exhibit a higher level of gratitude than men (Kashdan, Mishra, Breen, \& Froh, 2009; Krause, 2006). The dependencies may turn out to be more complex in the case of sociocultural gender (Bono \& Froh, 2009; Bruch, Berko, $\&$ Haase, 1998).

\section{RESEARCH PROBLEM}

As demonstrated in research thus far, women exhibit a higher level of gratitude compared to men and are able to derive greater benefits from this resource, e.g. deep and broad social ties (Kashdan et al., 2009). The presence of strong social ties correlates with the feeling of happiness (Argyle, 2001; Diener \& Seligman, 2002). Gratitude is considered the strongest predictor of positive well-being (Seligman \& Peterson, 2004). Therefore, we assume that psychological femininity may be positively correlated with positive orientation, while gratitude may reinforce the dependency between the variables. Thus, we decided to formulate the following research questions:

1. Do biological sex and socio-cultural gender differentiate the level of gratitude?

2. Are there links between femininity, masculinity, gratitude and positive orientation?

3. Can femininity and masculinity predict the intensity of gratitude?

4. Does gratitude act as a mediator in the relationship between femininity and masculinity versus positive orientation?

The obtained results will allow for a better understanding of differences between the sexes regarding positive emotions.

\section{PARTICIPANTS AND PROCEDURE}

\section{PARTICIPANTS}

The research was carried out in the spring of 2019 . The invitation to participate was published on the Internet - commercial advertising campaigns were used in search engines such as Google. The participation was anonymous and voluntary. All procedures performed in the study were in accordance with the ethical standards of the Committee for Ethics in Scientific Research of The Institute of Psychology, Polish Academy of Science (Research project approval \# 6/IV/2019). The research included 238 participants: $52 \%$ women $(n=125)$ and $48 \%$ men $(n=113)$. The average age of the participants in the research was $33.28(S D=8.95)$. The respondents were from the following provinces in Poland: Mazowieckie, Małopolskie and Dolnośląskie. $44 \%$ of the respondents lived in cities above 100,000 inhabitants $(n=105), 38 \%$ of respondents $(n=90)$ came from cities below 100,000 inhabitants and $18 \%$ lived in villages $(n=43)$. Out of all the respondents, 58\% ( $n=138)$ were married, $24 \%$ were unmarried $(n=57), 12 \%$ were divorced $(n=29)$ and $6 \%$ were widows/widowers $(n=14)$. The research also took into account education $-60 \%$ of the respondents had secondary education $(n=143), 25 \%$ of the respondents had higher education $(n=60)$ and $15 \%$ of the respondents had education lower than secondary $(n=35)$. The socio-cultural gender of the respondents varied (socio-cultural gender was determined based on the Masculinity and Femininity Scale) - 35\% were sex-typed $(n=84), 26 \%$ were androgynous $(n=62), 20 \%$ were cross-sex-typed $(n=47)$ and $19 \%$ were undifferentiated $(n=45)$. The detailed distribution on the basis of biological sex and socio-cultural gender is presented in Table 1.

\section{MEASURES}

In order to obtain answers to the questions above, the following research tools were employed:

The Masculinity and Femininity Scale (MAFS; Lipińska-Grobelny \& Gorczycka, 2011) is a two-factor tool designed to measure the socio-cultural gender in terms of Bem's (1974) gender patterns theory.

Table 1

Distribution of the group according to biological sex and socio-cultural gender

\begin{tabular}{lccccc}
\hline & $N$ & Sex-typed & Androgynous & Undifferentiated & Cross-sex-typed \\
\hline Women & 125 & 45 & 30 & 24 & 26 \\
Men & 113 & 39 & 32 & 21 & 21 \\
Total & 238 & 84 & 62 & 45 & 47 \\
\hline
\end{tabular}


The questionnaire contains 20 adjectives for the selfdescription of feminine and masculine features. The examined person expresses their attitude on a fivepoint scale ranging from 1 (I am definitely not like this) to 5 (I am definitely like this). Cronbach's $\alpha$ coefficient is .85 for the femininity scale and .76 for the masculinity scale.

The Gratitude Questionnaire (GQ-6; McCullough, Emmons, \& Tsang, 2002) in the Polish adaptation of Kossakowska and Kwiatek (2014) is a single-factor tool designed to measure gratitude as disposition. The questionnaire contains 6 statements. The examined person expresses their attitude on a seven-point scale ranging from 1 (I definitely disagree) to 7 (I definitely agree). Cronbach's $\alpha$ coefficient is .72.

The Positivity Scale (P Scale; Caprara et al., 2012) in the Polish adaptation of Łaguna, Oleś, and Filipiuk (2011) is a single-factor tool designed to measure positive orientation as a higher order latent variable that combines the components of optimism, self-esteem and life satisfaction. The questionnaire contains 8 statements. The examined person expresses their attitude on a five-point scale ranging from 1 (I definitely disagree) to 5 (I definitely agree). Cronbach's $\alpha$ coefficient is .78.

The form prepared by the authors to collect basic socio-demographic data.

\section{APPLIED STATISTICAL ANALYSES}

The data analysis was performed using SPSS version 25 . The normality of distributions was verified using the Kolmogorov-Smirnov test. Levene's test was used to verify the uniformity of variance. The conditions allowing the use of parametric tests were met. To determine the significance of differences, Student's $t$-test and the one- and two-way ANOVA were used. The magnitude of the effect based on the averages was checked using Cohen's $d$ index and partial $\eta^{2}$. In order to determine the relationships between variables, Pearson's correlation coefficient ( $r$ ) was applied. For the purpose of determining the predictors, a linear regression analysis was performed. Mediation analysis was used to establish the role of gratitude in the relationship between femininity and masculinity versus positive orientation. The significance of the model was tested using Sobel's test.

\section{RESULTS}

The average score on the scale of femininity is 36.20 $(S D=7.32)$. In the masculinity examination, an average score of $34.49(S D=7.46)$ was obtained. Due to the lack of data in the literature on the subject, the results could not be related to other studies using the MAFS questionnaire (in the text describing the tool construction, indicators of internal consistency and reliability were given; Lipińska-Grobelny \& Gorczyc$\mathrm{ka}, 2011)$.

In the gratitude test, the average score was 30.18 $(S D=6.93)$. The result turned out to correspond with the average for the construction sample of the Polish version of the GQ-6 questionnaire $(M=29.45$, $S D=6.04$; Kossakowska \& Kwiatek, 2014).

In the positive orientation examination, the average score was $28.23(S D=7.01)$. With regard to standards, the value should be considered as average, i.e. sten 5 . The result corresponds to the average for the Polish version of the $\mathrm{P}$ Scale construction sample $(M=29.30, S D=4.74$; Łaguna et al., 2011).

The average results of femininity, masculinity, gratitude and positive orientation are presented in Table 2.

Student's $t$-test confirmed the existence of statistically significant differences between women and men in terms of gratitude $(t=3.55, p<.001$, Cohen's $d=.46)$. Women $(M=31.66, S D=6.61)$ showed greater intensity of this emotion than men $(M=28.54$, $S D=6.93)$.

Two-way ANOVA for the intergroup plan in scheme 2 (biological sex) x 4 (socio-cultural gender) with a dependent variable gratitude revealed a significant main effect of the socio-cultural gender variable, $F(3,230)=21.61, p<.001, \eta^{2}=.22$. For the assessment of differences, post hoc comparisons were made using the Gabriel test method (recommended for unequal groups). Androgynous individuals showed a statistically significantly higher severity of gratitude $(M=34.69, S E=0.68)$ compared to other groups,

Table 2

Average results of the group in MAFS, GQ-6, P Scale $(N=238)$

\begin{tabular}{lcccccc}
\hline & Min & Max & $M$ & $S D$ & Skewness & Kurtosis \\
\hline Femininity & 14 & 50 & 36.20 & 7.32 & -.18 & .02 \\
Masculinity & 12 & 50 & 34.49 & 7.46 & -.14 & .07 \\
Gratitude & 8 & 42 & 30.18 & 6.93 & -.22 & -.27 \\
Positive orientation & 12 & 40 & 28.23 & 7.01 & -.18 & -.59 \\
\hline
\end{tabular}


i.e. sex-typed persons $(M=29.12, S E=0.59)$, crosssex-typed persons $(M=29.11, S E=0.79)$ or undifferentiated persons $(M=27.13, S E=0.80)$.

As a result of the analyses, a statistically significant effect of the interaction of biological sex and socio-cultural gender was obtained $F(3,230)=26.40$, $p<.001, \eta^{2}=.26$. The analysis of simple effects revealed that biological sex differentiates the results among the sex-typed and cross-sex-typed people statistically significantly. Sex-typed women $(M=34.16$, $S E=0.80)$ declared a significantly higher level of gratitude than sex-typed men $(M=23.31, S E=0.86)$. Cross-sex-typed women $(M=26.46, S E=1.05)$ achieved significantly lower results than cross-sextyped men $(M=32.38, S E=1.17)$. Other comparisons proved to be statistically insignificant. The average results of gratitude due to biological sex and sociocultural gender are presented in Figure 1.

In this study, sociodemographic data did not differentiate the results statistically significantly. One-way ANOVA showed that age differentiated subjects in terms of gratitude, $F(2,235)=11.95, p<.001, \eta^{2}=.09$, as well as in positive orientation, $F(2,235)=9.09$, $p<.001, \eta^{2}=.07$. Post hoc analysis using Gabriel's test confirmed that people aged $30-40(M=32.76, S D=5.49$, $n=79)$ achieved significantly higher scores in terms of gratitude than people under $30(M=27.92, S D=7.14$, $n=101)$ and people over $40(M=30.59, S D=7.10$, $n=58)$. People aged $30-40(M=30.81, S D=6.52)$ also obtained significantly higher scores regarding positive orientation than people under $30(M=26.52$, $S D=6.79)$ and people over $40(M=27.69, S D=7.13)$. Biological sex did not differentiate the results concerning positive orientation statistically significantly. Two-way ANOVA showed differences due to the socio-cultural gender, $F(3,230)=6.93, p<.001, \eta^{2}=.08$. Gabriel's test confirmed that androgynous individuals $(M=31.15, S E=0.82)$ achieved significantly higher results than sex-typed ones $(M=27.31, S E=0.70)$, as well as undifferentiated persons $(M=26.07, S E=0.96)$. A significant effect of biological sex and socio-cultural gender interactions was also obtained $F(3,230)=9.25$, $p<.001, \eta^{2}=.11$. Biological sex differentiated the results among sex-typed and cross-sex-typed people. Feminine women $(M=30.37, S E=0.96)$ declared a significantly higher level of positive orientation than masculine men $(M=23.77, S E=1.03)$. Cross-sex-typed women $(M=27.39, S E=1.26)$ achieved significantly lower results than cross-sex-typed men $(M=29.33$, $S E=1.40$ ). Other comparisons were found to be statistically insignificant.

Femininity was found to correlate positively with gratitude $(r=.55, p<.001)$ and positive orientation $(r=.34, p<.001)$. Masculinity did not correlate with any analyzed factor statistically significantly. In addition, there was a positive correlation between gratitude and positive orientation $(r=.50, p<.001)$.

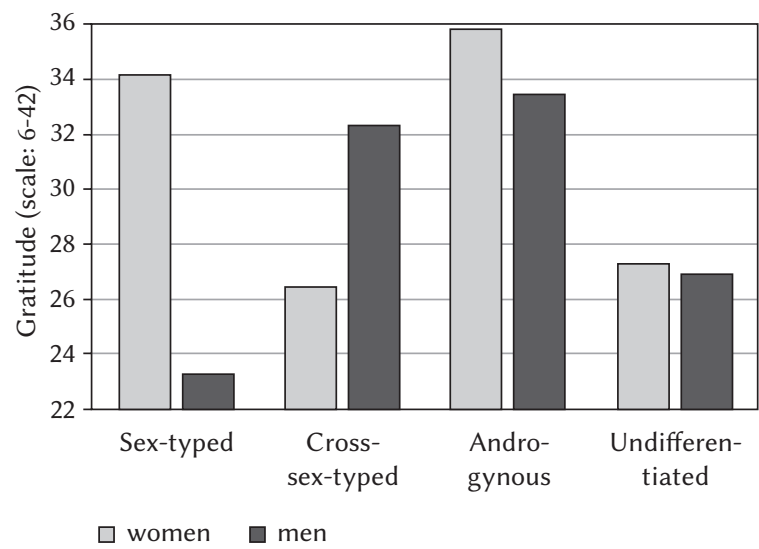

Figure 1. Differences in gratitude according to biological sex and socio-cultural gender $(N=238)$.

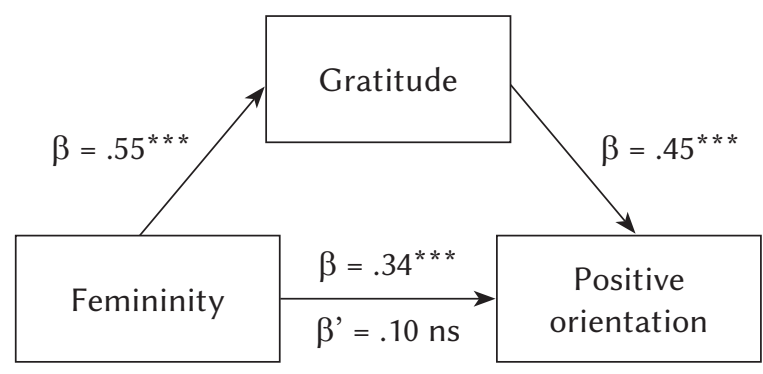

Note. ${ }^{* *} p<.001, \mathrm{~ns}-$ not significant.

Figure 2. Gratitude as a mediator in the relationship between femininity and positive orientation $(N=238)$.

The analysis of mediation showed that gratitude plays the role of a mediator in the relationship between femininity as an independent variable and a positive orientation as a dependent variable. The total effect was $\beta=.34(t=5.51, p<.001)$. The regression coefficient of the independent variable on the mediator was $\beta=.55(t=9.98, p<.001)$. The mediator regression coefficient on the dependent variable while controlling the independent variable was $\beta=.45(t=6.62, p<.001)$. Mediation reduced the strength of the relationship between femininity and positive orientation to a statistically insignificant one. The direct effect was $\beta^{\prime}=.10(t=1.42, p=.160)$. The model of full mediation was confirmed by the Sobel's test result $(z=5.50, p<.001)$. The mediation scheme is shown in Figure 2.

\section{DISCUSSION}

The literature on the subject suggested a positive influence of gratitude on well-being, appreciation and quality of life (Emmons \& Crumpler, 2000; Wolanin, 
2016), as well as building lasting social relationships, optimism, positive affect, happiness or lower intensity of anxiety and depression (Emmons \& McCullough, 2003). Our results are consistent with previous findings of researchers. We found a positive relationship between gratitude and positive orientation as a higher order latent variable that combines optimism, selfesteem, and life satisfaction.

Our analysis results indicated that women show a higher level of gratitude than men. Our findings are in line with previous reports in this respect (Kashdan et al., 2009; Krause, 2006). The difference in the average was even more pronounced when we looked at the socio-cultural gender, as well as the interaction between the biological sex and the socio-cultural gender. Androgynous individuals achieved higher scores in terms of gratitude than people who were sex-typed, undifferentiated or cross-sex-typed. This seems understandable as these individuals may exhibit more flexibility of behavior and sensitivity towards external requirements (Lipińska-Grobelny, 2007). Their situational adaptability results from the alternate use of feminine and masculine behavior patterns. Androgynous people tend to be more dominant, emotional and resistant to stress. They show a stronger personality, higher self-esteem or better health (Bem, 1975; Szpitalak \& Prochwicz, 2013). In addition, sex-typed women (so-called feminine women) achieved a much higher level of gratitude than sex-typed men (so-called masculine men). Similarly, cross-sex-typed women showed significantly lower scores than cross-sex-typed men. Our findings are consistent with previous research (Bono \& Froh, 2009; Bruch et al., 1998).

In our study, masculinity did not show a significant relationship with gratitude. Femininity favored and allowed for predicting gratitude $(\beta=.55)$. Therefore, it seems that the sources of gender differences in the sense of gratitude, in addition to biological and evolutionary factors, should be sought in the sociocultural conditioning of femininity and masculinity. In a stereotypical approach, a man should be strong, authoritarian and self-sufficient, which deviates from showing the need to be the object of bestowing (Bono \& Froh, 2009).

All the obtained results were moderate, but in our opinion, important. In previous studies, positive interventions aimed at gratitude revealed greater effectiveness than other techniques developed to improve well-being (Emmons \& McCullough, 2003; Lyubomirsky, Dickerhoof, Boehm, \& Sheldon, 2011; Seligman, Steen, Park, \& Peterson, 2005). It should be added that this is about strengthening the potential among healthy people, and not alleviating symptoms or disorders. It turns out that women (and, in the case of inclusion of the socio-cultural gender, androgynous persons and cross-sex-typed men) have a greater possibility to use this resource. In addition, the size of the effect obtained due to biological sex corresponds with previous studies in this field (Kashdan et al., 2009; Krause, 2006). It seems that its level may be correlated with other factors not included in the study. In the literature on the subject, the influence on the level of gratitude is attributed to upbringing, to reflexivity understood as recognition and acceptance of being the object of bestowing, preoccupation with material goods as well as inner mental patterns (Emmons, 2007; McWilliams \& Lependorf, 1990). In the latter case, the feeling of gratitude may be truly hampered by a subjective role of the victim (victim mentality) and the experience of suffering (Karpman, 1968). Another determinant turns out to be the sense of rightness and belonging (Kwiatek, 2012). Instead of feeling gratitude, the benefit can only be identified with the success of one's own work. Personality traits also have an impact on the level of gratitude. In McWilliams and Lependorf's (1990) study, narcissistic people connected gratitude with an unpleasant sense of insufficiency.

In our study, gratitude turned out to be a mediator in the relationship between femininity and positive orientation. This means that people with a higher level of femininity tend to show gratitude, which in turn increases the level of positive orientation.

Age turned out to differentiate the respondents due to gratitude and positive orientation. The highest level for both phenomena occurred in the period of middle adulthood. The obtained results correspond with the current results in this area (Allemand \& Hill, 2016; Caprara et al., 2012; Ruini \& Vescovelli, 2013). The relationships are of curvilinear character. The level of gratitude and positive orientation increases during adolescence and then decreases with the experience of aging. It seems, however, that it is not age itself that affects the evaluated phenomena, but rather other (unaccounted for) factors that may be correlated with it, e.g., stereotypes of aging (Pasik, 2005).

\section{LIMITATIONS}

All the applied tools were of a self-descriptive nature. The measurement could be susceptible to the response styles and social approval. Only the expression (giving) of gratitude was assessed in the study. The results may differ in the case of analyses of receiving gratitude. Despite the indicated limitations, this study introduces new data in the scope of the diversity of the level of gratitude due to biological sex and socio-cultural gender, as well as the relationships between femininity and gratitude and positive orientation. The obtained results will allow for a better understanding of differences between the sexes with regard to positive emotions, as well as the benefits from expressing and experiencing them. 


\section{CONCLUSIONS}

The study revealed differences between sexes regarding gratitude. Women showed a higher level of gratitude than men. Significant results pertained to sociocultural gender as well. Androgynous people showed a higher level of gratitude than people who are sextyped, undifferentiated and cross-sex-typed. Moreover, a significant effect of interaction between biological sex and socio-cultural gender was obtained. Sex-typed women showed a higher level of gratitude than sex-typed men. Women who are cross-sextyped showed a lower level of gratitude than crosssex-typed men. Furthermore, the study revealed the existence of positive relationships between femininity and gratitude and positive orientation. Gratitude turned out to be a mediator in the relationship between femininity and positive orientation - it was complete mediation.

\section{RefERENCES}

Alessandri, G., Caprara, G. V., \& Tisak, J. (2012). The unique contribution of positive orientation to optimal functioning: Further explorations. European Psychologists, 17, 44-54. https://doi.org/10.1027/ 1016-9040/a000070

Algoe, S. B., Haidt, J., \& Gable, S. L. (2008). Beyond reciprocity: Gratitude and relationships in everyday life. Emotion, 8, 425-429. https://doi.org/ 10.1037/1528-3542.8.3.425

Allemand, M., \& Hill, P. L. (2016). Gratitude from early adulthood to old age. Journal of Personality, 84, 21-35. https://doi.org/10.1111/jopy. 12134

Argyle, M. (2001). The psychology of happiness. New York, NY: Taylor and Francis Inc.

Beck, A. T. (1967). Depression: Clinical, experimental, and theoretical aspects. Philadelphia, PA: University of Pennsylvania Press.

Bem, S. L. (1974). The measurement of psychological androgyny. Journal of Consulting and Clinical Psychology, 42, 155-162. https://doi.org/10.1037/ h0036215

Bem, S. L. (1975). Sex role adaptability: One consequence of psychological androgyny. Journal of Personality and Social Psychology, 31, 634-643. https:// doi.org/10.1037/h0077098

Bono, G., \& Froh, J. (2009). Gratitude in school: Benefits to students and schools. In R. Gilman, E. Huebner, \& M. Furlong (Eds.), Handbook of positive psychology in schools (pp. 77-88). New York, NY: Routledge.

Brody, L. R. (1997). Gender and emotion: Beyond stereotypes. Journal of Social Issues, 53, 369-394. https://doi.org/10.1111/j.1540-4560.1997.tb02448.x

Bruch, M. A., Berko, E. H., \& Haase, R. F. (1998). Shyness, masculine ideology, physical attractiveness, and emotional inexpressiveness: Testing a mediational model of men's interpersonal competence. Journal of Counseling Psychology, 45, 84-97. https://doi.org/10.1037/0022-0167.45.1.84

Büssing, A., Wirth, A. G., Humbroich, K., Gerbershagen, K., Schimrigk, S., Haupts, M., Baumann, K., \& Heusser, P. (2013). Faith as a resource in patients with multiple sclerosis is associated with a positive interpretation of illness and experience of gratitude/awe. Evidence-Based Complementary and Alternative Medicine, 2013, e128575. https:// doi.org/10.1155/2013/128575

Caprara, G. V., Alessandri, G., Eisenberg, N., Kupfer, A., Steca, P., Caprara, M. G., Yamaguchi, S., Fukuzawa, A., \& Abela, J. (2012). The Positivity Scale. Psychological Assessment, 24, 701-712. https://doi. org/10.1037/a0026681

Danner, D. D., Snowdon, D. A., \& Friesen, W. V. (2001). Positive emotions in early life and longevity: Findings from the nun study. Journal of Personality and Social Psychology, 80, 804-813. https://doi. org/10.1037/0022-3514.80.5.804

Diener, E., \& Seligman, M. E. (2002). Very happy people. Psychological Science, 13, 80-83.

Emmons, R. A. (2007). Thanks! How the new science of gratitude can make you happier. Boston, MA: Houghton Mifflin Harcourt.

Emmons, R. A. (2009). The John Templeton Foundation. In S. J. Lopez \& A. Beauchamp (Eds.), Encyclopedia of positive psychology (pp. 988-990). New York, NY: Oxford University Press.

Emmons, R. A., \& Crumpler, C. A. (2000). Gratitude as a human strength: Appraising the evidence. Journal of Social and Clinical Psychology, 19, 5669. https://doi.org/10.1521/jscp.2000.19.1.56

Emmons, R. A., \& McCullough, M. E. (2003). Counting blessings versus burdens: Experimental studies of gratitude and subjective well-being. Journal of Personality and Social Psychology, 84, 377-389. https://doi.org/10.1037/0022-3514.84.2.377

Fredrickson, B. L. (2004a). Gratitude, like other positive emotions, broadens and builds. In R. A. Emmons \& M. E. McCullough (Eds.), The psychology of gratitude (pp. 145-166). New York, NY: Oxford University Press.

Fredrickson, B. L. (2004b). The broaden-and-build theory of positive emotions. Philosophical Transactions of the Royal Society. Series B: Biological Sciences, 359, 1367-1377. https://doi.org/10.1098/ rstb.2004.1512

Gruszecka, E. (2011). Wdzięczność a szczęśliwe życie [Gratitude and subjective well-being]. Psychologia Spoteczna, 6, 316-329.

Ingoldsby, B. B., Horlacher, G. T., Schvaneveldt, P. L., \& Matthews, M. (2005). Emotional expressiveness and marital adjustment in Ecuador. Marriage and Family Review, 38, 25-44. https://doi.org/10.1300/ J002v38n01_04 
Karpman, S. (1968). Fairy tales and script drama analysis. Transactional Analysis Bulletin, 7, 39-43.

Kashdan, T. B., Mishra, A., Breen, W. E., \& Froh, J. J. (2009). Gender differences in gratitude: Examining appraisals, narratives, the willingness to express emotions, and changes in psychological needs. Journal of Personality, 77, 691-730. https:// doi.org/10.1111/j.1467-6494.2009.00562.x

Knopp, K. A. (2012). Czy kobiety naprawdę są bardziej inteligentne emocjonalnie niż mężczyźni? O różnicach międzypłciowych w zakresie zdolności emocjonalnych [Are women really more emotionally intelligent than men? Gender differences in emotional abilities]. Kwartalnik Naukowy Towarzystwa Uniwersyteckiego Fides et Ratio, 4, 95-112.

Kossakowska, M., \& Kwiatek, P. (2014). Polska adaptacja kwestionariusza do badania wdzięczności GQ-6 [The Polish adaptation of the Gratitude Questionnaire (GQ-6)]. Przeglad Psychologiczny, 57, 503-514.

Krause, N. (2006). Gratitude toward God, stress, and health in late life. Research on Aging, 28, 163-183. https://doi.org/10.1177\%2F0164027505284048

Kuczyńska, A. (2002). Płeć psychologiczna idealnego i rzeczywistego partnera życiowego oraz jej wpływ na jakość realnie utworzonych związków [Type of gender schema of ideal and real life partner and its influence on the quality of formed relationships]. Przegląd Psychologiczny, 45, 385-399.

Kwiatek, P. (2012). Przeszkody i strategie rozwoju wdzięczności w świetle współczesnych badań psychologicznych [Gratitude: obstacles and enhancement strategies in the frame of contemporary psychology]. Seminare. Poszukiwania Naukowe, 32, 151-163.

Lambert, N. M., \& Fincham, F. D. (2011). Expressing gratitude to a partner leads to more relationship maintenance behavior. Emotion, 11, 52-60. https:// doi.org/10.1037/a0021557

Levant, R. F., \& Kopecky, G. (1995). Toward the reconstruction of masculinity. In R. F. Levant \& W. S. Pollack (Eds.), A new psychology of men (pp. 229-251). New York, NY: Basic Books.

Lipińska-Grobelny, A. (2007). Podmiotowe uwarunkowania męskości, kobiecości i androgynii [Subjective indicators of masculinity, femininity and androgyny]. Folia Psychologica, 11, 3-19.

Lipińska-Grobelny, A., \& Gorczycka, K. (2011). Rekonstrukcja narzędzia do pomiaru płci psychologicznej [The reconstruction of a technique to assess psychological gender]. Przegląd Psychologiczny, 54, 179-192.

Lyubomirsky, S. (2008). Wybierz szczęście. Naukowe metody budowania życia, jakiego pragniesz [The how of happiness: a new approach to getting the life you want]. Warsaw: Laurum.

Lyubomirsky, S., Dickerhoof, R., Boehm, J. K., \& Sheldon, K. M. (2011). Becoming happier takes both a will and a proper way: an experimental longi- tudinal intervention to boost well-being. Emotion, 11, 391-402. https://doi.org/10.1037/a0022575

Łaguna, M., Oleś, P., \& Filipiuk, D. (2011). Orientacja pozytywna i jej pomiar: Polska adaptacja Skali Orientacji Pozytywnej [Positive orientation and its measure: Polish adaptation of the Positivity Scale]. Studia Psychologiczne, 49, 47-54.

Markus, H., Crane, M., Bernstein, S., \& Siladi, M. (1982). Self-schema and gender. Journal of Personality and Social Psychology, 42, 38-50. https://doi. org/10.1037/0022-3514.42.1.38

Matczak, A., \& Knopp, K. A. (2013). Znaczenie inteligencji emocjonalnej w funkcjonowaniu człowieka [The importance of emotional intelligence in human functioning]. Warsaw: Liberi Libri.

McCraty, R., Atkinson, M., Tiller, W. A., Rein, G., \& Watkins, A. D. (1995). The effects of emotion on short term power spectrum analysis on heart rate variability. American Journal of Cardiology, 76, 1089-1093. https://doi.org/10.1016/S0002-9149(99) 80309-9

McCullough, M. E., Emmons, R. A., \& Tsang, J. A. (2002). The grateful disposition: a conceptual and empirical topography. Journal of Personality and Social Psychology, 82, 112-127. https://doi. org/10.1037/0022-3514.82.1.112

McCullough, M. E., Kilpatrick, S. D., Emmons, R. A., \& Larson, D. B. (2001). Is gratitude a moral affect? Psychological Bulletin, 127, 249-266. https://doi. org/10.1037/0033-2909.127.2.249

McWilliams, N., \& Lependorf, S. (1990). Narcissistic pathology of everyday life: The denial of remorse and gratitude. Contemporary Psychoanalysis, 26, 430-451. https://doi.org/10.1080/00107530.1990.10 746671

Pasik, M. (2005). Wyznaczniki jakości życia u osób w wieku emerytalnym [Determinants of quality of life in people over expected retirement age]. Folia Psychologica, 9, 65-79.

Polak, E. L., \& McCullough, M. E. (2006). Is gratitude an alternative to materialism? Journal of Happiness Studies, 7, 343. https://doi.org/10.1007/s10902005-3649-5

Ruini, C., \& Vescovelli, F. (2013). The role of gratitude in breast cancer: Its relationships with posttraumatic growth, psychological well-being and distress. Journal of Happiness Studies, 14, 263-274. https://doi.org/10.1007/s10902-012-9330-x

Schwartz, S. H., \& Rubel, T. (2005). Sex differences in value priorities: Cross-cultural and multimethod studies. Journal of Personality and Social Psychology, 89, 1010-1028. https://doi.org/10.1037/00223514.89.6.1010

Seligman, M. E., \& Peterson, C. (2004). Character strengths and virtues: a handbook and classification. New York, NY: Oxford University Press.

Seligman, M. E., Steen, T. A., Park, N., \& Peterson, C. (2005). Positive psychology progress: Empirical val- 
idation of interventions. American Psychologist, 60, 410-421. https://doi.org/10.1037/0003-066X.60.5.410

Shaffer, D. R. (2000). Social and personality development. Belmont, CA: Thomson Learning.

Skalski, S. (2019). The mediating role of perceived social support in relation to resiliency and positive orientation. Social Dissertations, 13, 28-37. https:// doi.org/10.29316/rs/112978

Solomon, R. C. (1995). The cross-cultural comparison of emotion. In J. Marks \& R. T. Ames (Eds.), Emotions in Asian thought (pp. 253-294). Albany, NY: State University of New York Press.

Spence, J. T., Helmreich, R. L., \& Stapp, J. (1974). The Personal Attributes Questionnaire: a measure of sex-role stereotypes and masculinity and femininity. Journal of Personality and Social Psychology, 32, 29-39.

Szpitalak, M., \& Prochwicz, K. (2013). Płeć psychologiczna osób z depresją kliniczną. Doniesienia wstępne [Psychological gender in clinical depression. Preliminary study]. Psychiatria Polska, 47, 53-64.

Tsang, J. A. (2006). Gratitude and prosocial behavior: an experimental test of gratitude. Cognition and Emotion, 20, 138-148. https://doi.org/ 10.1080/02699930500172341

Tsang, J. A., \& Martin, S. R. (2019). Four experiments on the relational dynamics and prosocial consequences of gratitude. The Journal of Positive Psychology, 14, 188-205. https://doi.org/10.1080/17439 760.2017.1388435

Tucholska, S. (2017). Wdzięczność: jej natura i rodzaje [Gratitude: characteristics and types]. Rocznik Filozoficzny lgnatianum, 22, 75-99.

Trzebińska, E. (2005). Cechy afektywne a jakość życia. Porównanie kobiet i mężczyzn [Gender related differences in affective traits and quality of life]. Kolokwia Psychologiczne, 13, 15-31.

Valikhani, A., Ahmadnia, F., Karimi, A., \& Mills, P. J. (2019). The relationship between dispositional gratitude and quality of life: The mediating role of perceived stress and mental health. Personality and Individual Differences, 141, 40-46. https://doi. org/10.1016/j.paid.2018.12.014

Wolanin, A. (2016). Rozwój w kierunku szczęścia w psychologii pozytywnej: trening sił charakteru a dobrostan człowieka [Development towards happiness in positive psychology: character strengths training and human's well-being]. Rynek - Spoteczeństwo - Kultura, 4, 26-31.

Wytykowska, A., \& Petrides, K. V. (2007). Inteligencja emocjonalna jako dyspozycja. Polska adaptacja skali do badania inteligencji emocjonalnej jako cechy: TEIQue Petridesa i Furnhama [Polish adaptation of the scale to the study of emotional intelligence as a trait: TEIQue by Petrides and Furnham]. Psychologia, Edukacja i Spoteczeństwo, 4, 97-110. 